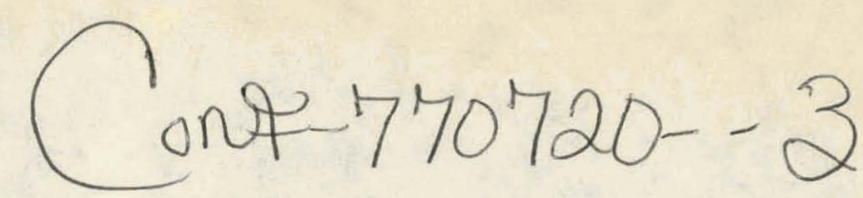

\title{
ASSESSMENT OF POTENTIAL RADIATION DOSE-TO-MAN \\ FROM AN ACUTE TRITIUM RELEASE INTO A FOREST ECOSYSTEM
}

by

J. R. Watts and C. E. Murphy, Jr.

Savannah River Laboratory

E. I. du Pont de Nemours and Company

Aiken, South Carolina 29801

A paper proposed for presentation

at Health Physics Society 22nd Annual Meeting

July 3-8, 1977, Atlanta, Georgia

and for publication in Health Physics

This paper was prepared in connection with work under Contract No. AT (07-2)-1 with the U.S. Energy Research and Development Administration. By acceptance of this paper, the publisher and/or recipient acknowledges the U.S. Government's right to retain a nonexclusive, royalty-free 1 icense in and to any copyright covering this paper, along with the right to reproduce and to authorize others to reproduce all or part of the copy-

righted paper.

- NOTICE- account of work This report was prepared as an accoum or Neither sponsored by the United States United States Energy the United
Research and Development Administration, contractors, their emplinyees, not therr empluyees, makes legal subcontrace express or implied, or asscy, completeness wanility or responsibitity for tion, apparatus, product or or usefulness of any informatents that its use would no process disclosed, or represhts. 


\section{DISCLAIMER}

This report was prepared as an account of work sponsored by an agency of the United States Government. Neither the United States Government nor any agency Thereof, nor any of their employees, makes any warranty, express or implied, or assumes any legal liability or responsibility for the accuracy, completeness, or usefulness of any information, apparatus, product, or process disclosed, or represents that its use would not infringe privately owned rights. Reference herein to any specific commercial product, process, or service by trade name, trademark, manufacturer, or otherwise does not necessarily constitute or imply its endorsement, recommendation, or favoring by the United States Government or any agency thereof. The views and opinions of authors expressed herein do not necessarily state or reflect those of the United States Government or any agency thereof. 


\section{DISCLAIMER}

Portions of this document may be illegible in electronic image products. Images are produced from the best available original document. 


\section{ASSESSMENT OF POTENTIAL RADIATION DOSE-TO-MAN \\ FROM AN ACUTE TRITIUM RELEASE INTO A FOREST ECOSYSTEM*}

by

\section{J. R. Watts, and C. E. Murphy, Jr. \\ Savannah River Laboratory \\ E. I. du Pont de Nemours and Company \\ Aiken, South Carolina 29801}

ABSTRACT - On May 2, 1974, 479,000 curies of tritium gas escaped from a 3avallial River plant exhaust stack. The tritium first reached the ground in a pine forested area and was partially assimilated into the ecosystem. Samples of vegetation collected and measured for a period of 70 days showed an increase in the levels of tritiated water. Cycling of the tritium retained in the forest ecosystem resulted in a higher concentration of tritiated water vapor in the air at breathing height near the forest floor than that calculated by the usual models used for predicting air concentration. In addition, the model for tritium cycling in the forest predicts a diurnal cycle of tritiated water vapor concentration with higher concentrations at night when air movement under the canopy is slower.

The potential dose to the maximum individual because of inhalation and skin absorption of tritium as HTO after the release was calculated three ways: 1) by using the body water model from the International Commission

* Work done under USERDA Contract No. AT(07-2)-1. 
on Radiological Protection (ICRP) Publication 2 and assimilation during the passage of the puff; 2) by using the body water model from the ICRP Publication 2 and assimilation during an extended exposure period to tritium determined by the experimental measurements; and 3) by using a three-compartment dosimetry model with retention half times of 9,30 , and 450 days with the extended exposure period used in 2). The potential doses were $0.14,0.80$, and $0.89 \mathrm{mrem}$, respectively. These potential doses show the necessity of considering the interaction of radioactive material with the ecosystem for dose calculation.

\section{INTRODUCTION}

The widespread occurrence of tritiated water (HTO) in the ecosystems and the ease of analysis of HTO has led to the study of the dynamics of tritium-in-man (Wo70, Pi57, Bu65, Sa67). Limited information exists on tritium in the ecosystems, although field studies have been carried out in some regions (Fi74, Jo70). An evaluation of the health physics consequences of an accidental atmospheric tritium release in the western United States has given some additional information (My73).

This paper assesses the potential dose-to-man from the passage of a tritium cloud and the residual tritium following an accidental release to the atmosphere from the Savannah River Plant.

\section{RELEASE}

A tritium release occurred at the Savannah River Plant (SRP) May 2, 1974. At 0700 EST, 479,000 curies of tritium gas was released during a period of about four minutes (Ma74). More than $99 \%$ of the radioactivity 
was molecular tritium, and the remainder was tritium oxide. The tritium gas mixture was released at a height of $200 \mathrm{ft}$ through an $8-\mathrm{ft}$ diameter exhaust stack. The air in the exhaust stack had an exit velocity of $2700 \mathrm{ft} / \mathrm{min}$. Meteorological conditions were classified as Pasquill Type C (neutral stability). Wind direction was 210 to $225^{\circ}$ with a speed of $2 \mathrm{~m} / \mathrm{sec}$. The release first touched the ground at the plant boundary approximately $16 \mathrm{~km}$ from the release point.

\section{MONITORING RESULTS}

Immediately after the tritium release, environmental samples were collected along the predicted trajectory for a period of 70 days. Samples measured for tritium showed that the maximum tritium uptake occurred at the plant boundary, $16 \mathrm{~km}$ from the release point. HTO concentrations were found in air moisture, surface water, soil, and vegetation.

Some of the HTO released was assimilated directly into the forest ecosystem in the area of touchdown. The tritiated water entered the free water component by diffusion and by direct exchange of tritiated water for nontritiated plant and soil water. Although this direct exchange of HTO was high enough to explain equilibrium levels of tritiated water initially found in plants and soil, conversion of molecular tritium to tritiated water was suggested by the patterns of uptake. Murphy (1976a) showed that suil microorganisms and plants converted molecular tritium to HTO, and the highest concentrations of the HTO were found in the soil. The higher tritium concentrations in the soil indicate that this conversion was a significant source of HTO for the ecosystem. The HTO can diffuse and/or exchange between soil and plants, maintaining an 
elevated air concentration after the initial puff has passed. Since the release was $>99 \%$ molecular tritium, conversion could exert a significant effect on the potential dose-to-man.

\section{MODELING ECOSYSTEM TRITIUM CYCLING}

A model was developed to simulate the absorption of molecular tritium by forests and the subsequent release of tritiated water to the atmosphere. The calculated values from the model agreed with the measured values of soil, pine tree needles, and air concentrations of HTO following the release of May 1974 (Fig. 1). The model which predicted a gradient of tritiated water vapor concentration during the initial 2-1/2-day period following the release showed that the highest concentration occurred in the soil; an intermediate concentration, in the air near the forest floor; and a lower concentration, in the pine tree needles. This pattern was found in the samples taken immediately after the release. The model also predicted that the concentration of tritiated water in the air and vegetation was higher at night than in the day (Fig. 2). During the day, the air from above the canopy freely mixes with air under the canopy. At night, the air movement under the canopy is slower, and the air concentration under the canopy approaches equilibrium with the soil surface concentration.

Rain occurred $2-1 / 2$ days after the release. The tritiated water in the surface soil was displaced downward and no longer influenced the water vapur content of the air by direct vapor exchange. After the rain, the concentration of tritiated water vapor in the air near the ground was lower than the equilibrium concentration in the pine tree needles. 
However, a diurnal air concentration cycle persisted. During this latter stage of the cycling process, the air concentration approached equilibrium with the pine tree needle concentration at night.

\section{DOSE MODELS}

To apply tritium uptake models to man, the tritium inhaled as HTO is assumed to be exchanged with water vapor in the respiratory tract and to - be retained in the body. An individual immersed in an atmosphere containing HTO receives an assimilation from skin absorption equal to that from inhalation (Pi57). No internal dose results from molecular tritium (HT or $\mathrm{T}_{2}$ ) as conversion by the body of HT to HTO is less than $7 \times 10^{-3} \%$.

The internal dosimetry model for HTO used for environmental dose evaluation at SRP was described in the International Commission on Radiological Protection (ICRP) Publication 2 (Pe59). In this model, tritium enters the body water by skin absorption and inhalation and remains there until eliminated. The elimination rate is described by a single exponential (one-compartment model) with an effective half time of 12 days. The radiation dose from the HTO is evenly partitioned to the $42 \mathrm{~kg}$ of body water. A quality factor of 1.7 is used in this model. Contrasted to this one-compartment model, later investigators have proposed a three-compartment model consisting of the body water and two compartments representing the tritium that is bound to organic molecules. As early as 1957, Pinson and Langham observed an organic binding or exchange in both chronic and acute exposures to tritium. Synder et al. (Sn68) monitored an acute uptake for 255 days after the inhalation and suggested the data could be described by using a two-compartment model 
consisting of body water and a bound component. Sanders and Reinig did a definitive analysis of an acute uptake observed for 415 days (Sa67). Their data was described by a three-compartment model: body water and two bound compartments. Bennett examined several cases of acute human assimilation (Be72). Initial rate of elimination was described by a single exponential with observed average half times of 8.5 to 9.5 days. Bennett observed that the data from Snyder et al. can be described by a threecompartment model such as that of Sanders and Reinig. After surveying available data, Bennett suggests a three-compartment model: body water (A) and two bound chemical compartments (B and C) defined as exchangeable tissue bound and nonexchangeable tissue bound (Fig. 3). The two bound compartments are not identifiable with specific tissues or organs. The retention half times of these compartments are 9, 30, and 450 days, respectively.

\section{DOSE COMPARISONS}

The potential dose to the maximum individual was calculated by three methods (I, II, and III) in Table 1: Method I is the body water model from ICRP Publication 2 and assimilation during passage of the puff; Method II is the same body water model from ICRP Publication 2 but with an extended exposure period to tritium as determined by experimental measurements; and Method III is the three-compartment model with the extended exposure period.

Charactcristics of lhe passage of the radioactive cloud were calculated by standard Gaussian diffusion techniques (Si68) in Method I. By using measured meteorological parameters, this method gave an integrated 
dilution factor of $1 \times 10^{-6} \mathrm{sec} / \mathrm{m}^{3}$ for a distance of $16 \mathrm{~km}$ from the release point. The tritium assimilation resulted from the calculated onehour cloud exposure and a breathing rate of $20.8 \mathrm{~L} / \mathrm{min}\left(10 \mathrm{~m}^{3} / 8 \mathrm{hr}\right)$. The dose to an individual is $0.14 \mathrm{mrem}$ with a 12 -day half time and a quality factor of 1.7 .

In Method II the dose was calculated by Method I with the addition of an extended source term of the tritium air concentrations. During the first eight days, the air concentrations were based on measurements and modeling techniques. After the eighth day, air concentrations were determined from a nonlinear least squares regression equation fit tn sample data. The air concentration was described by the sum of two exponential decay equations with half times of 2.47 and 22.7 days (Mu76b). The breathing rate of the reference man is $20 \mathrm{~L} / \mathrm{min}$ for 8 hours working and 8 hours of nonoccupational activity and $7.5 \mathrm{~L} / \mathrm{min}$ for 8 hours resting (Re75). A resting period from 2200 to 0600 coordinates with the diurnal cycling of the tritium concentration. The dose to an individual is 0.80 mrem with the one-compartment body water model.

In Method III, the three-compartment model with half times of 9,30 , and 450 days that more nearly reflect tritium transport within the body and the extended source of Method II were used. The potential dose to an individual of 0.89 mrem was calculated by using this dosimetry model.

The similar value of dose between the dosimetry models of Methods II and 111 results from the different half times of 9 and 12 days for the major compartment, body water. The 12-day half time of the one-compartment model almost compensates for the small compartments of 30 and 450 days of the three-compartment model. 


\section{CONCLUSION}

The potential dose to an individual from a tritium release is significant $1 y$ affected by the ecosystem in which the material is deposited. In the observed system, the forest ecosystem increased the maximum dose from $0.14 \mathrm{mrem}$ to $0.80 \mathrm{mrem}$. Deposition of tritium into a region of herbaceous vegetation would lower the dose as compared to a forest ecosystem because HTO has a shorter half-1ife in herbaceous vegetation (Ma74). Dosimetry calculations based solely on exposure during passage of a cloud are clearly inadequate for radioactive materials which interact with the ecosystem.

Table 1. Calculated potential doses to the maximm individual

Calculation Method

I

I I

II I
Dosimetry Model

Body water (Pe59)

Body water (Pe59)

3-compartment (Be72)
Exposure

Cloud passage

Ecosystem retention

Ecosystem retention
Dose, mrem

0.14

0.80

0.89

\section{REFERENCES}

Be72 Bennett B. G., 1972, Radiation Dose Due to Acute Intake of Tritium

by Man, USAEC Report HASL-253, New York Health and Safety Laboratory, New York, NY.

Bu65 Butler H. L. and Lcroy J. H., 1965, "Observations of Biological Half-Life of Tritium," Health Plys. 11, 283-285. 
Fi74 Final Report of the Radiological Sumeizlance Progrom for the Project Gasbuggy Production Test, May 15, 1973 to November 6, 1973, 1974, USERDA Report NERC-LV-539-30, U.S. National Environmenta1 Research Center, Las Vegas, NV.

Jo70 Jordon C. F., Koranda J. J., Kline J. R., and Martin J. R., 1970, "Tritium Movement in a Tropical Ecosystem," Bioscience 20, 807.

Ma74 Marter W. L., 1974, Environmental Effects of a Tritium Gas Release from the Savannah River Plant on May 2, 1974, USAEC Report DP-1369, Savannah River Laboratory, E. I. du Pont de Nemours and Co., Aiken, SC. Mu76a Murphy C. E., Jr., Boni A. L., and Tucker S. P., 1976, The Conversion of Gaseous Molecular Tritium to Tritiated Water in Biological Systems, USERDA Report DP-1442, Savannah River Laboratory, E. I. du Pont de Nemours and Co., Aiken, SC, Mu76b Murphy C. E., Jr., Watts J. W., and Corey J. C., "Environmental Tritium Transport from Atmospheric Release of Molecular Tritium," Health Phys. (in press).

My73 Myers D. S., Tinney J. F., and Gudiksen P. H., 1973, "Health Physics Aspects of a Large Accidental Tritium Release," in: Tritium (Edited by Moghissi A. A. and Carter M. W.), pp. 611-623 (Phoenix, AZ: Messenger Graphics).

Pe59 Permissible Dose for Internal Radiation, 1959, International

Commission on Radiological Protection, Recommendations of the ICRP, Repurt of Lommittee II, ICRP Publication 2, Pergammon Press, New York, NY. Pi57 Pillson E. A. and Longham W. H., 1957, "Physiology and Toxicology of Tritium in Man," J. Appl. Physiol. 10(1), 108-126. 
Re75 Report of the Task Group on Reference Man, 1975, Internationa1 Commission on Radiological Protection, Recommendations of the ICRP, Report of a Task Group of Committee II, ICRP Publication 23, Pergammon Press, New York, NY.

Sa67 Sanders S. M., Jr. and Reinig W. C., "Assessment of Tritium in Man," in: Proceedings of Symposium on Diagnosis and Treatment of Deposited Radionuclides, May 15-17, 1967, IAEA Symposium, Richland, WA.

S168 Slade D. H., 1968, Meteorology and Atomic Energy, TID-24190

(Springfield: Clearinghouse for Federal Scientific and Technical Information).

Sn68 Snyder W. S., Fish B. R., Bernard S. R., Ford M. R., and Muir J. R., 1968, "Urinary Excretion of Tritium Following Exposure of Man to HTO-a A Two Exponential Model," Phys. Med. Biol. 13(4), 547-559.

Wo70 Woodward H. Q., 1970, The Biological Effects of Tritizom, prepared by Sloan Kettering Institute for Cancer Research for New York Health and Safety Laboratory, USAEC Report HASL-229, NY. 


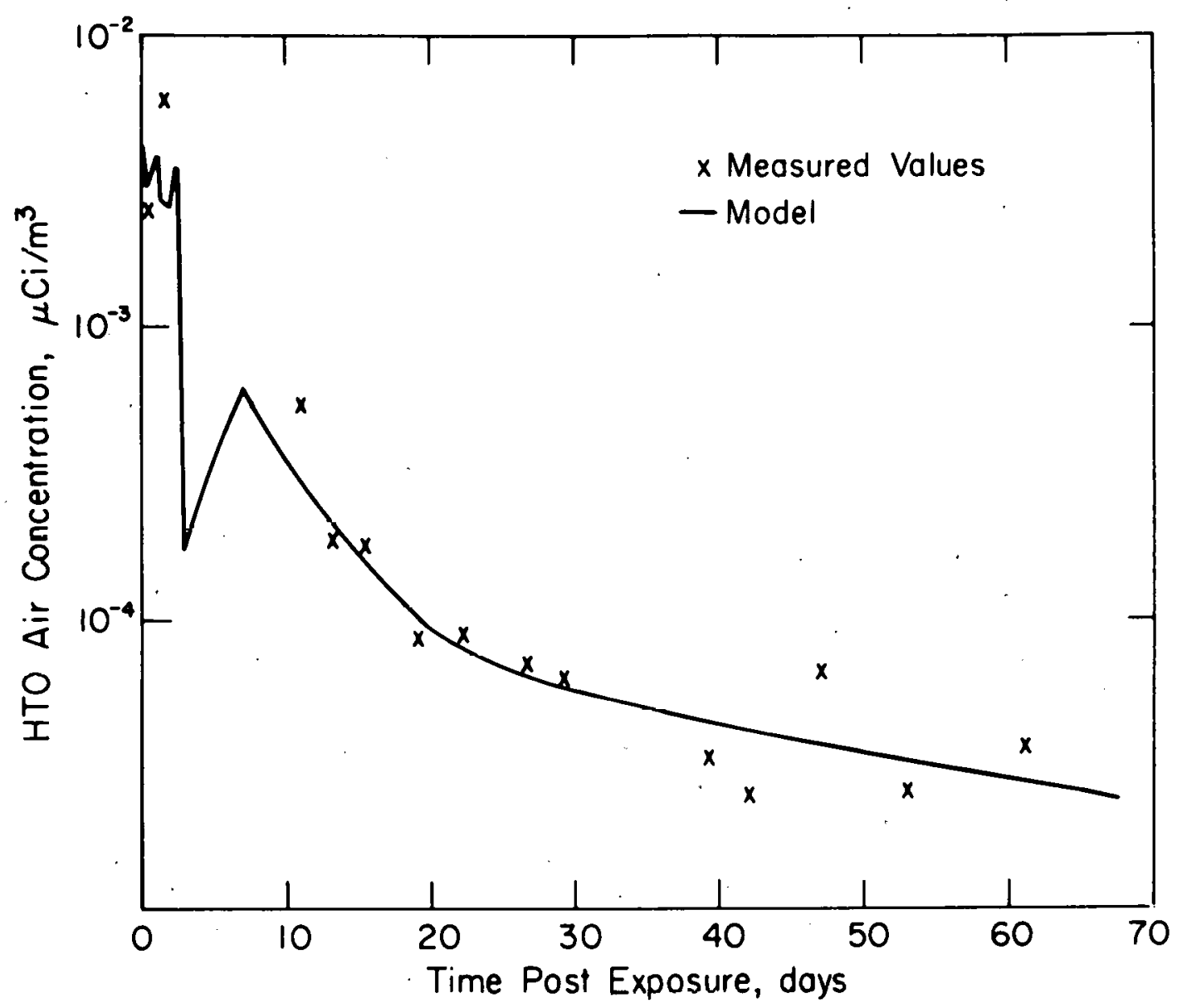

FIG. 1. Comparison of measured and mode1-predicted HTO concentrations in breathing-level air. 


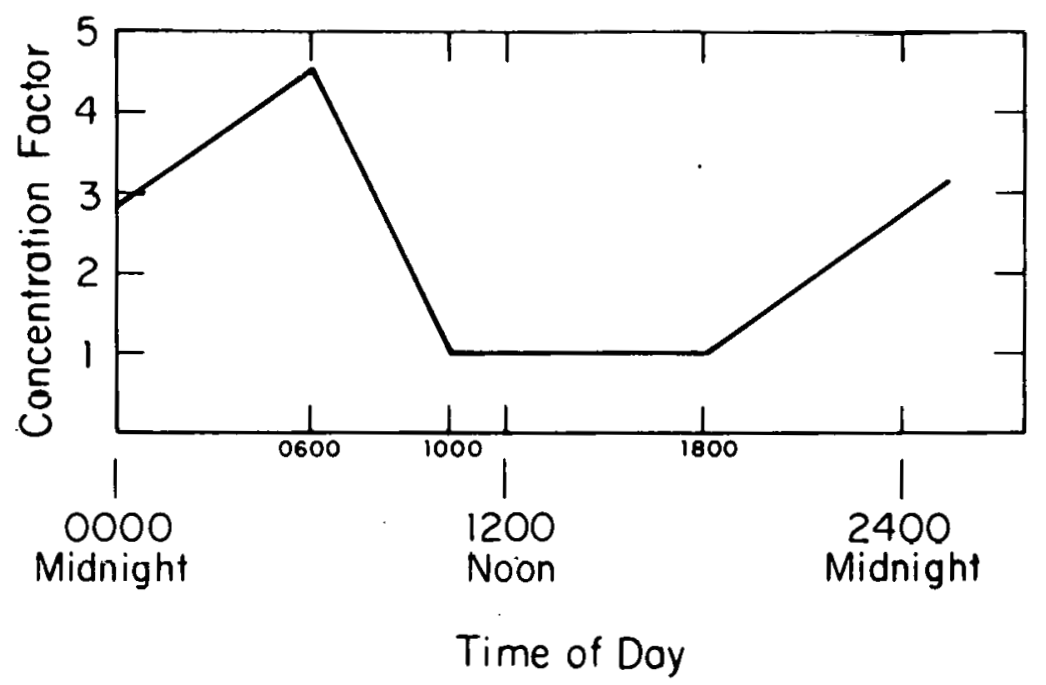

FIG. 2. Diurnal cycling of HTO concentration in the air. The concentration factor is relative to the measured value in the afternoon. 


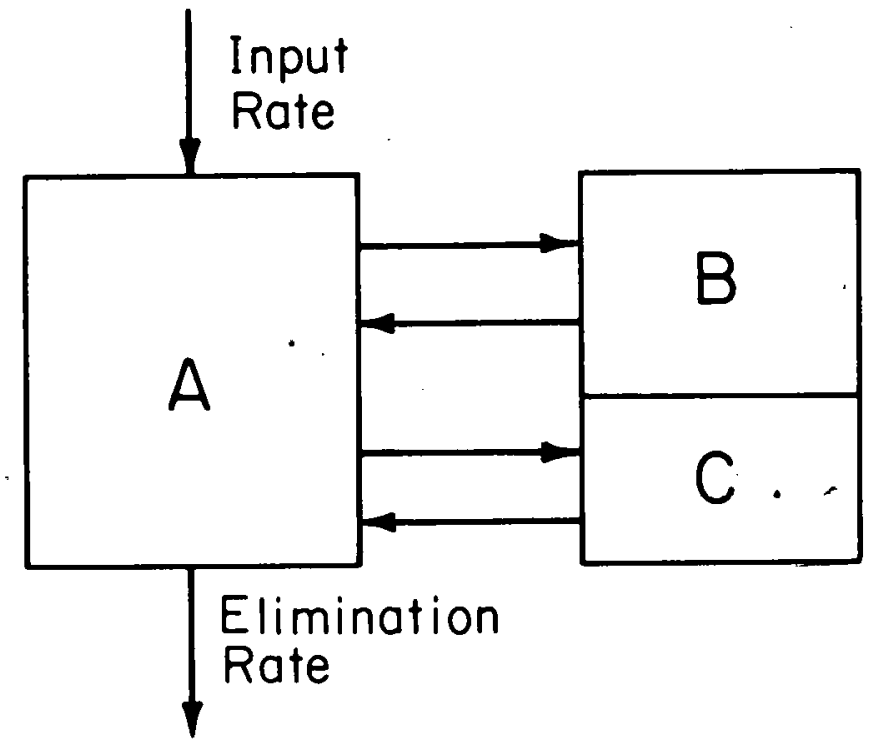

FIG. 3. Three-compartment model of tritium dynamics in vivo. Compartment $\mathrm{A}$ is the body water, and compartments $\mathrm{B}$ and $\mathrm{C}$ are bound tritium components. 